\title{
A comunicação forma cidadãos ou consumidores?
}

Marcylenne Caper

A avalanche de informações de diferentes tipos de assunto que nos inunda diariamente nas mídias sociais e na vida cotidiana afasta cada vez mais a possibilidade de discernir o que realmente importa ser ingerido. A variedade de conteúdo gerado, aceito no ambiente acadêmico por gerar um olhar plural, nos conduz ao naufrágio da produção do conhecimento.

A proposta nesta pesquisa é ampliar o exame já introduzido por outros autores ao questionar o excesso de informação recebida no século XXI. Seria possível separar o bom do medíocre?, como refletiu Shirky (2012). A velocidade com que o volume recebido se processa também contribui para a falta de compreensão. Estamos consumindo informações como objetos de moda, descartáveis em cada estação. A quantidade ganha da qualidade.

A convivência em um mundo que caminha depressa, com pessoas que agem de forma individual sem serem capazes de pensar no próximo, afasta as relações embasadas nos valores éticos. Que oportunidades tem a ética no mundo globalizado dos consumidores? Pensamos que o questionamento de Bauman (2011) deve ser retomado no âmbito das novas formas de comunicação que a internet nos propicia.

$\mathrm{Na}$ informação fragmentada atualmente recebida, surge o conteúdo patrocinado, que também merece aqui uma reflexão na busca do entendimento sobre a formação do cidadão no mundo de hoje. A leitura entrecortada por anúncios acaba por afastar a reflexão.

Desta forma, o estudo vai tentar trazer para o centro dos debates, em um primeiro momento, a interferência na qualidade da informação recebida de forma ágil, que traduz uma superficialidade gerada por esta nova dinâmica. Aqui as ideias de Carr (2012) serão utilizadas. Em seguida, sugerir que o mundo da publicidade interfere na maneira como o homem de hoje percebe e constrói a informação. A criatividade neste aspecto é posta em cheque. As colocações de Scorcelli e Vaz (2014) esclarecem esse aspecto. E, por último, apontar algumas pistas de ação que recupere a preocupação com a formação do indivíduo e sua cidadania, requisito básico para qualquer sociedade saudável.

\section{Muita produção, pouco conteúdo}

Em recente estudo publicado na Revista Radis, Eliane Bardanachvili (2015,p.24-28) comenta a preocupação da comunidade científica e acadêmica com a ênfase em critérios quantitativos na avaliação dos programas de pós-graduação da Coordenação de Aperfeiçoamento de Pessoal de Ensino Superior (Capes/MEC). Alerta para a busca desenfreada por aumentar a produção científica, sem almejar a qualidade.

A preocupação na área da Saúde Coletiva pode ser deslocada para a abundância de produções nos meios de comunicação no mundo digital, que mistura o trabalho profissional 
com o amador, e elimina a figura do editor, como alertou Shirky: "o resultado é a ruptura do velho padrão de separação profissional entre o bom e o medíocre antes da publicação; agora essa filtragem é cada vez mais social e acontece a posteriori”. (2012,p.72)

O tempo na era digital é o principal inimigo da tentativa de filtrar o que se recebe. A preocupação em checar a veracidade da informação passou a ter papel secundário, quando o que importa é usufruir de imediato todo o material disponível, volume que aumenta a cada segundo. A sensação de impotência pela incapacidade de responder a demanda traduz o vazio que só é preenchido por mais informação, em um ciclo vicioso. O que resta é uma camada superficial de conhecimentos soltos e desconexos.

David Brooks, popular colunista do "New York Times", citado por Nicholas Carr (2012) em seu trabalho "O que a Internet está fazendo com os nossos cérebros", fala da geração superficial: "(...) mas então percebi que a magia da era da informação é que ela nos permite saber menos". Carr faz uma interessante reflexão sobre a memória que sofre com o uso de artifícios externos: "quando estamos on-line, entramos em um ambiente que promove a leitura descuidada, o pensamento apressado e distraído e o aprendizado superficial” (p.161).

As facilidades no acesso à tecnologia para produzir todo e qualquer tipo de comunicação afasta a necessidade, e acrescentamos: até mesmo o desejo de produzir conhecimento. Acabamos por reproduzir material já existente. Pouco se cria com a oferta abundante na Web. E o pior, as plataformas multimídias dispersam o pensamento reflexivo. "Informação não é conhecimento". Foi o que alertou Gisela Madureira, redatora publicitária, em entrevista recente na obra que compara as mudanças na publicidade, depois do computador, ao se referir ao aprendizado de seus alunos: "São duas coisas bem diferentes. Eles têm informação à disposição muito mais do que tivemos, mas não significa que isso se transforme, naturalmente, em conhecimento". (2014,p.24).

O que percebemos é um consumo exagerado de postagens, que misturam conteúdos e alimentam o individualismo. Bauman $(2011, \mathrm{p}, 37)$ reflete a dificuldade de amar ao próximo, exigência ética fundamental para a convivência humana no mundo globalizado de hoje, que enaltece a postura de ganhos individuais e nos faz insensíveis a dor do outro.

Infelizmente, compartilhar a informação é apenas uma forma de exibição contrária à proposta de transmitir o saber adquirido. Administrar melhor o tempo utilizado nas redes sociais, filtrar a informação recebida, com a preocupação de repassar o que há de melhor para a formação do próximo, são possíveis caminhos para fortalecer a cidadania.

Concordamos com Barros Filho (2014,p.35) ao afirmar que a saída passa pela ética e deve ser aplicada o quanto antes: "A ética é a inteligência compartilhada (...) se formos esperar uma sociedade ideal para a ética existir, é possível que ela não venha a existir nunca (...) a ética é um saber prático". Não podemos perder tempo. 
Para refletir:

1. Como alimentar o desejo de produzir e repassar conhecimento hoje?

2. A sensibilidade perante o outro está de fato comprometida no mundo digital?

\section{Bibliografia:}

Bauman, Zygmunt. A Ética é possível num mundo de consumidores? Rio de Janeiro: Zahar,2011.

Bardanachvili, Eliane. Quantidade não é Qualidade. Revista Radis (Programa Radis de Comunicação e Saúde). Rio de Janeiro: Fiocruz, № 152, maio 2015.

Carr, Nicholas. O que a internet está fazendo com os nossos cérebros. A geração superficial. Rio de Janeiro, Agir, 2011.

Cortella, Mario Sergio e Barros Filho, Clovis. Ética e vergonha na cara. Campinas, SP:Papirus 7 Mares,2014.

Scorcelli,Edson;Carvalho, Cristina Vaz de. Publicidade AC/DC (antes e depois do computador). Rio de Janeiro: Sinergia,2014.

SHIRKY, Clay. Lá vem todo mundo. Rio de janeiro: Zahar, 2012. 